\title{
[41] Mitochondrial A'TPase Complex from Neurospora crassa
}

\author{
By Walter Sebald and Gerd Wild
}

The ATPase complex has been isolated from mitochondria of Neurospora crassa by immunological techniques. The protein can be obtained rapidly and quantitatively in high purity by micro- or large-scale immunoprecipitation. Immunoprecipitation has been applied to labeled and doubly labeled mitochondrial proteins in order to investigate the number and molecular weights of subunit polypeptides, the site of synthesis of subunit polypeptides, and the dicyclohexylcarbodiimide-binding protein. The ATPase complex obtained by large-scale immunoprecipitation has been used as starting material for the isolation of hydrophobic polypeptides.

\section{Principle}

The $\mathrm{F}_{1}$ moiety of the complex is solubilized by chloroform treatment of the mitochondria. ${ }^{1,2}$ The purified $\mathrm{F}_{1}$ protein is used to raise antibodies in rabbits. The whole ATPase complex is then precipitated by antiserum to $F_{1}$ from mitochondria solubilized by Triton $X-100 .^{3,4}$

\section{Purification of $F_{1}$}

Chemicals and Stock Solutions

Sucrose, reagent grade

Chloroform, reagent grade

Ammonium sulfate, reagent grade

DEAE-cellulose (DE-52, Whatman)

Bio-Gel A-0.5 m, 100-200 mesh (Bio-Rad)

$\mathrm{KCl}, 3 M$

Tris-acetate, $1 M$, pH 7.5

EDTA, $0.1 M$, pH 7.5

ATP, $0.5 M$, pH 7.5

${ }^{1}$ R. B. Beechey, S. A. Hubbard, P. E. Linnet, A. D. Mitchell, and E. A. Munn, Biochem. J. 148, 533 (1975).

${ }^{2}$ K. Takeshige, B. Hess, M. Böhm, and H. Zimmermann-Telschow, Hoppe-Seyler's Z. Physiol. Chem. 357, 1605 (1976).

${ }^{3}$ A. Tzagoloff and P. Meagher, J. Biol. Chem. 246, 7328 (1971).

${ }^{4}$ G. Jackl and W. Sebald, Eur. J. Biochem. 54, 97 (1975). 


\section{Buffers}

STE: sucrose, $0.25 M$; Tris-acetate, $10 \mathrm{~m} M$, pH 7.5; EDTA, $1 \mathrm{~m} M$

TEA: Tris-acetate, $10 \mathrm{~m} M$, pH 7.5; EDTA, $1 \mathrm{~m} M$; ATP, $2 \mathrm{~m} M$

Procedure. Mitochondria are isolated in the presence of the protease inhibitor phenylmethylsulfonyl fluoride. All operations are performed at room temperature.

Mitochondria suspended in TEA (10 mg protein per milliliter) and an equal volume of chloroform are gently shaken in tight centrifuge tubes until a homogeneous emulsion has formed $(1-5 \mathrm{~min})$. Centrifugation at $10,000 \mathrm{~g}$ for $10 \mathrm{~min}$ yields a chloroform phase, a large amount of insoluble protein at the interphase, and a slightly turbid, yellowish water phase. The combined water phases are cleared by high-speed centrifugation $(20,000 \mathrm{~g}$ for $15 \mathrm{~min})$ and immediately applied to columns of DEAEcellulose (each $20 \mathrm{~g}$ DEAE per $3 \mathrm{~g}$ mitochondria) equilibrated with TEA. The columns are washed with TEA $(50 \mathrm{ml})$ and thereafter with TEA plus $30 \mathrm{~m} M \mathrm{KCl}$ until all brown-colored material is removed (about $200 \mathrm{ml}$ ). The $\mathrm{F}_{1}$-containing protein is eluted as a yellow band with TEA plus 0.3 $M \mathrm{KCl}$.

The eluted protein is precipitated by addition of solid ammonium sulfate $(50 \mathrm{~g} / 100 \mathrm{ml})$ and then dissolved in a minimal volume of TEA (30$40 \mathrm{mg} / \mathrm{ml}$ ). After a clarifying centrifugation $(20,000 \mathrm{~g}$ for $5 \mathrm{~min})$ the solution (up to $10 \mathrm{ml}$ ) is applied to a column of Bio-Gel A-0.5m (1-liter bed volume) equilibrated with TEA. The column is operated at a flow rate of $30-40 \mathrm{ml} / \mathrm{hr}$; the effluent is monitored at $280 \mathrm{~nm}$. The $F_{1}$ protein is eluted in $60-90 \mathrm{ml}$ shortly after the void volume.

The yield and enrichment of $F_{1}$ during purification are shown in Table I. Separation of the protein by dodecyl sulfate gel electrophoresis reveals the presence of only the five characteristic subunits (see Fig. 3B). Sometimes, however, additional faint bands are observed; they can be removed by a second chromatography on DEAE-cellulose eluting with a linear $\mathrm{KCl}$ gradient $(20-300 \mathrm{mM})$. The $\mathrm{F}_{1}$ protein is precipitated by addition of solid ammonium sulfate $(50 \mathrm{~g} / 100 \mathrm{ml})$ and stored at $0^{\circ}$.

\section{Preparation of Antiserum}

The $F_{1}$ antiserum is raised in rabbits. The $F_{1}$ protein dissolved in TEA $(2-4 \mathrm{mg} / \mathrm{ml})$ is mixed with an equal volume of complete Freund's adjuvant (Difco Labs.). One milliliter of the emulsion corresponding to 1-2 mg $F_{1}$

${ }^{5}$ O. H. Lowry, N. J. Rosebrough, A. L. Farr, and R. J. Randall, J. Biol. Chem. 193, 265 (1951).

${ }^{6}$ A. Tzagoloff, J. Biol. Chem. 244, 5020 (1969). 
TABLE I

Yield and Enrichment of $F_{1}$ ATPAse During Purification ${ }^{a}$

\begin{tabular}{|c|c|c|c|}
\hline Step & $\begin{array}{c}\text { Total protein (\% } \\
\text { of starting } \\
\text { material) }\end{array}$ & $\begin{array}{l}\text { Total ATPase } \\
\text { activity (\% of } \\
\text { starting } \\
\text { material) }\end{array}$ & $\begin{array}{c}\text { Specific ATPase } \\
\text { activity } \\
\left(\mu \mathrm{mol} \mathrm{P}_{\mathrm{i}} / \min \times\right. \\
\text { mg protein) }\end{array}$ \\
\hline Mitochondria & 100 & 100 & $2-3$ \\
\hline Water phase after chloroform treatment & 25 & $80-90$ & $8-12$ \\
\hline $\begin{array}{l}\text { Eluate after chromatography on DEAE- } \\
\text { cellulose }\end{array}$ & $6-7$ & 80 & $30-40$ \\
\hline $\begin{array}{l}\text { Eluate after chromatography on Bio- } \\
\text { Gel A-0.5m }\end{array}$ & $1-2$ & 40 & $60-80$ \\
\hline
\end{tabular}

"Protein was determined by the method of Lowry at al. ${ }^{5}$ The ATPase activity was measured with ATP as substrate as described. ${ }^{6}$

is injected subcutaneously into the neck at four different positions. The injection is repeated 4 weeks later with $2-4 \mathrm{mg} \mathrm{F}_{1}$ protein. After another 2 weeks the antiserum is collected. Small quantities of blood are taken from the ear vein. Usually the rabbits are bled by a cut into the aorta. The serum is obtained by centrifugation of the clotted blood and stored at $-20^{\circ}$.

Titers are determined by a titration experiment (see Fig. 2). One to three milliliters antiserum precipitate $1 \mathrm{mg}$ ATPase complex. Antisera with higher titers usually yield immunoprecipitates that are dissociated by dodecyl sulfate to only a very small extent.

\section{Immunoprecipitation of ATPase Complex}

As an example, a small-scale immunoprecipitation is described which is performed in a microcentrifuge tube of $1.4 \mathrm{ml}$ (Fa. Eppendorf, Hamburg, Germany) shown in Fig. 1. The mitochondria are radioactively labeled by in vivo incorporation of $\left[{ }^{3} \mathrm{H}\right]$ - or $\left[{ }^{14} \mathrm{C}\right]$ leucine. ${ }^{4,7}$ All operations are performed at $0^{\circ}$.

Mitochondria corresponding to $1 \mathrm{mg}$ are suspended in $0.4 \mathrm{ml} 10 \mathrm{mM}$ Tris-acetate, $\mathrm{pH}$ 7.5. Fifty microliters $3 \mathrm{M} \mathrm{KCl}$ and $50 \mu \mathrm{l} 10 \%$ Triton X$100(\mathrm{w} / \mathrm{v})$ are added. The suspension clears immediately. Minor insoluble material (less than $5 \%$ of total protein) is removed by centrifugation $(12,000 \mathrm{~g}$ for $5 \mathrm{~min})$ in a microcentrifuge. The supernatant is incubated with antiserum to $F_{1}(0.2-0.5 \mathrm{ml}$ antiserum per milligram mitochondrial protein). The precipitation is complete after $1-4 \mathrm{hr}$. The precipitate is

${ }^{7}$ W. Sebald, S. Werner, and H. Weiss, this series, in press. 
separated by centrifugation $(12,000 \mathrm{~g}$ for $2 \mathrm{~min})$. The protein is washed three times with $1 \mathrm{ml} 10 \mathrm{~m} M$ Tris-acetate, $\mathrm{pH} \mathrm{7.5,} \mathrm{by} \mathrm{resuspension} \mathrm{and}$ centrifugation. The protein is resuspended by means of a pestle fitting exactly into the microcentrifuge tube (Fig. 1). The washed immunoprecipitate is essentially white. The protein corresponding to about $0.15 \mathrm{mg}$ ATPase complex is suspended in $20 \mu 110 \mathrm{mM}$ Tris-acetate buffer; the polypeptides are then dissociated by addition of $50 \mu$ l dodecyl sulfate buffer [ $2 \%$ dodecyl sulfate $(\mathrm{w} / \mathrm{v})$ in $0.1 \mathrm{M}$ Tris-acetate, $\mathrm{pH} 8.5]$. The solution is incubated overnight in an ice bath. Disaggregation of polypeptides may be incomplete in immunoprecipitates obtained with some antisera. In such instances disaggregation can be accomplished by addition of $5 \%$ mercaptoethanol $(\mathrm{v} / \mathrm{v})$.

The results of a titration of ATPase complex with $F_{1}$ antiserum is shown in Fig. 2. Maximally, about $15 \%$ of whole mitochondrial protein is recovered in the immunoprecipitate. Control serum only gives minimal reaction (less than $0.3 \%$ ). The precipitation is highly specific, since the ATPase complex and cytochrome oxidase immunoprecipitated from the same solution exhibit completely different polypeptide patterns when analyzed by dodecyl sulfate gel electropheresis. ${ }^{4}$

\section{Properties}

Subunit Composition. The immunoprecipitated ATPase complex is resolved by dodecyl sulfate gel electrophoresis into 13 polypeptide bands.

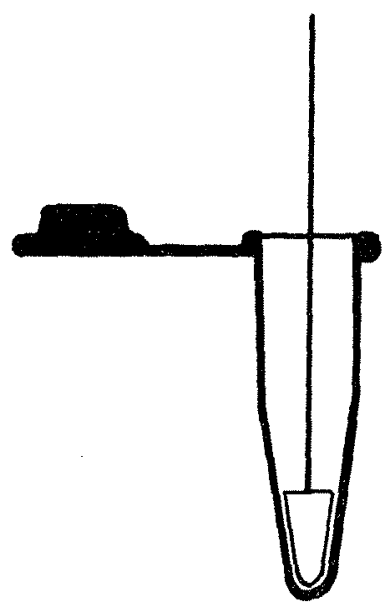

FIG. 1. Resuspension of immunoprecipitates. The pestle consists of Plexiglas polymerized in the microcentrifuge tube together with the handle. 


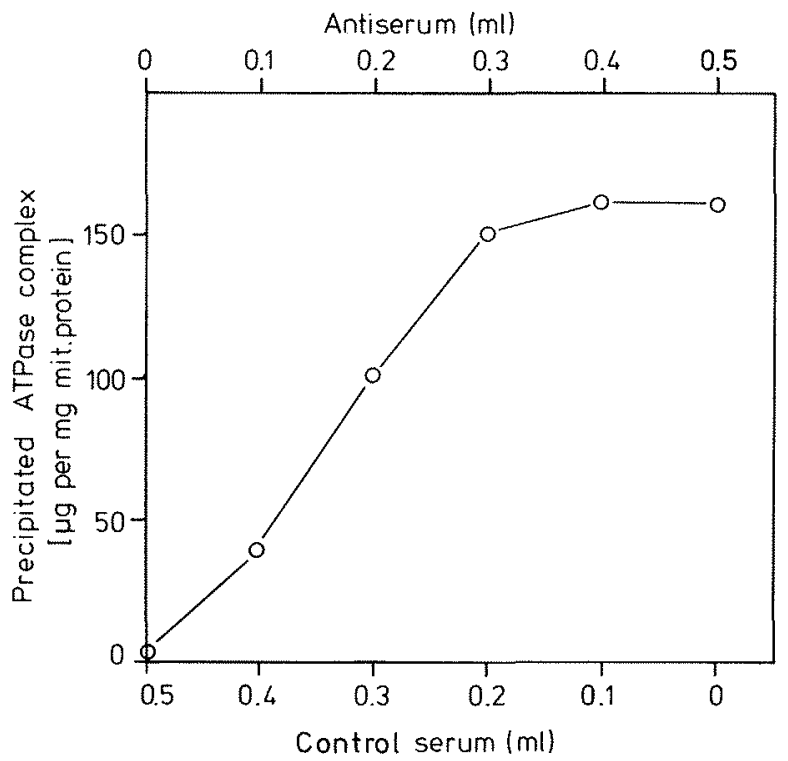

FIG. 2. Titration of Triton X-100-solubilized mitochondrial proteins with antiserum to $F_{1}$. The immunoprecipitates were isolated as described in the text. Samples of $0.5 \mathrm{ml}$ corresponding to $1 \mathrm{mg}$ solubilized protein were incubated with $0.5 \mathrm{ml}$ rabbit serum. Control and antiserum to $F_{1}$ were added in amounts as indicated on the abscissas. Protein was determined by a homogeneous $\left[{ }^{3} \mathrm{H}\right]$ leucine label. ${ }^{7}$

The molecular weights range from 59,000 to 8000 (Fig. 3). The polypeptides can be visualized by staining the gels with Coomassie brillant blue (Fig. 3A; the rabbit immunoglobulins do not interfere with the ATPase polypeptides). Figure $3 \mathrm{C}$ shows a separation of an ATPase complex labeled homogeneously with $\left[{ }^{14} \mathrm{C}\right] l$ eucine. The radioactive polypeptides can be correlated with those observed in the densitometric trace. The polypeptide bands of 19,000 and 8000 daltons, however, which are low in the densitometric trace of the stained gel, are quite prominent in the $\left[{ }^{14} \mathrm{C}\right]$ leucine radioactivity pattern. They contain 7 and $13 \%$ of the total leucine label, respectively. ${ }^{4}$ Hence, at least one molecule of the 19,000 dalton component and six molecules of the 8000-dalton component are present per ATPase complex of 500,000 daltons.

The five polypeptides of molecular weights of $59,000,56,000,36,000$, 15,000 and 12,000 daltons can be correlated with the subunits of $F_{1}$ (Fig. $3 \mathrm{~B}, \mathrm{C})$. They appear to occur in both proteins in the same quantitative relations not only in the densitometric traces but also in the distribution of the leucine label. 

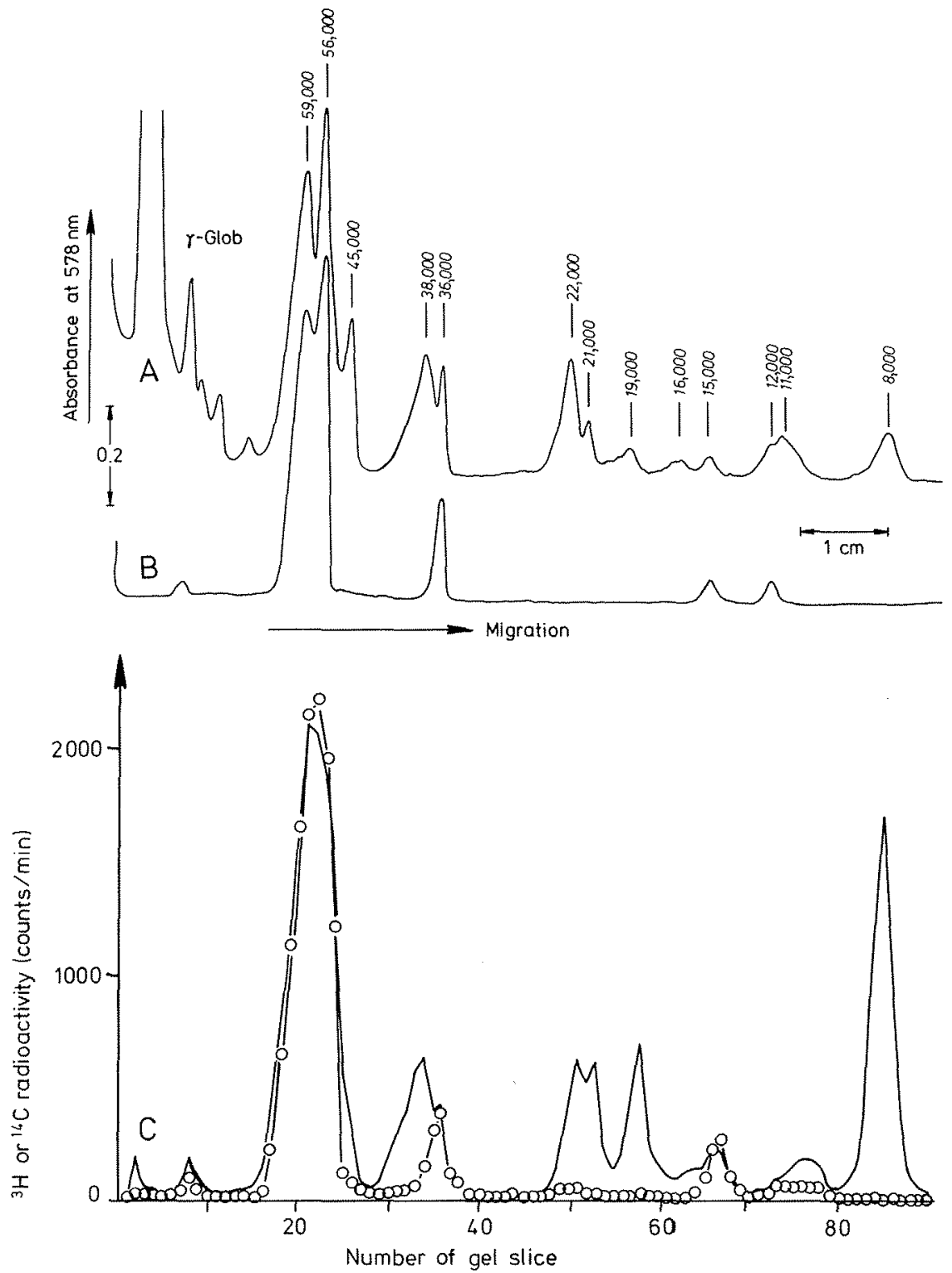

FIG. 3. Subunit composition of immunoprecipitated ATPase complex and $F_{1}$ ATPase. All polypeptides were separated on $12.5 \%$ polyacrylamide gels by electrophoresis in the presence of dodecyl sulfate. (A) Twenty micrograms ATPase complex and (B) $10 \mu \mathrm{g} F_{1}$ ATPase were separated on the same gel slab and stained with Coomassie Brillant Blue. (C) $\left[{ }^{14} \mathrm{C}\right]$ Leucine-labeled ATPase complex $\left(6 \times 10^{6} \mathrm{cpm}\right.$ per milligram protein) and $\left[{ }^{3} \mathrm{H}\right]$ leucinelabeled $\mathrm{F}_{1}$ ATPase $\left(0.6 \times 10^{6} \mathrm{cpm}\right.$ per milligram protein) were dissolved in dodecyl sulfate buffer, mixed, and subjected to gel electrophoresis $\left(24,000 \mathrm{cmp}{ }^{3} \mathrm{H}\right.$ and $\left.40,000 \mathrm{cpm}{ }^{14} \mathrm{C}\right)$. The proteins were labeled by growing cells for $2 \mathrm{hr}$ in the presence of $\left[{ }^{14} \mathrm{C}\right]$ leucine and $\left[{ }^{3} \mathrm{H}\right]$ leucine, respectively. ${ }^{7}$ 
TABLE II

Amino Acid Composition of the Protein Components of the ATPase Complex ${ }^{\prime}$

\begin{tabular}{lrrrr} 
& \multicolumn{4}{c}{ Amount in component (mol/100 mol) } \\
\cline { 2 - 5 } Amino acid & $\mathrm{F}_{1}$ & 19,000 -dalton & 11,000 -dalton & 8000 -dalton \\
\cline { 2 - 5 } Asx & 8.04 & 7.1 & 5.13 & 5.27 \\
Thr & 5.50 & 4.75 & 4.15 & 2.61 \\
Ser & 5.08 & 9.06 & 11.17 & 6.52 \\
Glx & 12.64 & 6.05 & 5.23 & 6.78 \\
Pro & 4.21 & 4.01 & 7.21 & 1.95 \\
Gly & 9.31 & 8.01 & 2.71 & 14.2 \\
Ala & 10.65 & 7.86 & 2.18 & 17.1 \\
Cys & 0.62 & $n . d$. & $n . d$. & - \\
Val & 8.67 & 4.56 & 7.59 & 6.91 \\
Met & 1.97 & 1.08 & 1.27 & 4.02 \\
Ile & 6.31 & 11.85 & 9.28 & 6.52 \\
Leu & 8.97 & 16.56 & 13.83 & 12.9 \\
Tyr & 2.35 & 3.05 & 4.24 & 2.46 \\
Phe & 3.61 & 9.63 & 12.54 & 7.25 \\
Lys & 5.56 & 1.41 & 7.32 & 2.82 \\
His & 1.17 & 2.55 & - & - \\
Arg & 5.18 & 2.48 & 6.16 & 2.72 \\
Trp & n.d. & n.d. & n.d. & - \\
Polarity & 43.2 & 33.4 & 39.2 & 26.7 \\
\hline Samp & & & & \\
\hline
\end{tabular}

"Samples of the isolated proteins were hydrolyzed for $24,48,72$, and $120 \mathrm{hr}$ in $6 \mathrm{M}$ $\mathrm{HCl}$ at $105^{\circ}$. Cysteine was determined as cysteic acid and methionine as methionine sulfone after peroxidation.

${ }^{b}$ n.d., not determined.

The smallest polypeptide of the ATPase complex has been identified as the dicyclohexylcarbodiimide-binding protein. It is isolated from the immunoprecipitate or from whole mitochondrial protein in pure form by extraction with neutral chloroform-methanol (proteolipid) ${ }^{8,9}$

The 45,000 and 38,000-dalton polypeptides of the immunoprecipitated ATPase complex appear not to be essential for oligomycin-sensitive ATPase complex activity. They are not found in preparations of the functional enzyme. ${ }^{8}$

The polypeptides of 19,000 and 11,000 daltons are synthesized on mitochondrial ribosomes, whereas all other polypeptides including the

${ }^{8}$ W. Sebald, Biochim. Biophys. Acta 463, 1 (1977).

${ }^{9}$ W. Sebald, T. Graf, and G. Wild, in "Genetics and Biogenesis of Chloroplasts and Mitochondria"' (T. Bücher et al., eds.), p. 167. North-Holland Publ., Amsterdam, 1976. 
proteolipid are synthesized outside the mitochondria..$^{4,9}$ The assembly of the ATPase complex ceases within 5-10 min when mitochondrial protein synthesis is inhibited. This indicates that the mitochondrially synthesized polypeptides of 19,000 and 11,000 daltons are true subunits of the ATPase complex.

Amino Acid Compositions. The polypeptides of 19,000 and 11,000 daltons can be isolated from the immunoprecipitate by gel chromatography and preparative gel electrophoresis in the presence of dodecyl sulfate. ${ }^{8}$ Their amino acid composition is shown in Table II together with that of the proteolipid (isolated by chloroform-methanol extraction) and that of $F_{1}$. The proteolipid of 8000 daltons and the polypeptide of 19,000 daltons exhibit the most hydrophobic amino acid composition. The polar residues amount to only $27 \%$ and $33 \%$, respectively. The low amounts of basic residues present may explain why both polypeptides stain poorly with Coomassie brillant blue. In the polypeptide of 11,000 daltons the basic amino acids prevail over the acidic ones. The polarity ${ }^{10}$ of $39 \%$ is relatively high but still lower than that of the water-soluble $F_{1}$ protein $(43 \%)$.

${ }^{10}$ R. A. Capaldi and G. Vanderkooi, Proc. Natl. Acad. Sci. U.S.A. 69, 930 (1972).

\title{
[42] Oligomycin-Sensitive ATPase of Saccharomyces cerevisiae
}

\author{
By Alexander Tzagoloff
}

$$
\mathrm{ATP}+\mathrm{H}_{2} \mathrm{O} \rightarrow \mathrm{ADP}+\mathrm{P}_{1}
$$

The oligomycin-sensitive ATPase complex of yeast mitochondria is analogous to the ATPase complex of mammalian mitochondria and consists of three functionally distinct components: (1) a water-soluble and oligomycin-insensitive ATPase called $\mathrm{F}_{1}$, (2) a membrane factor consisting of four subunit proteins that confer oligomycin sensitivity on $F_{1}$, and (3) oligomycin-sensitivity-conferring protein (OSCP), which functions in the attachment of $F_{1}$ to the membrane factor. ${ }^{1}$ Both $F_{1}$ and the oligomycin-sensitive ATPase complex have been purified from mitochondria of Saccharomyces cerevisiae. Methods have also been devised for the purification of the subunit proteins of $F_{1}$.

\footnotetext{
${ }^{1}$ A. Tzagoloff, Enzymes Biol. Membr. 4, 103 (1976).
} 